\title{
Assessment of the Need for Nitrogen, Phosphorus, Potassium, and Sulfur Preplant Nutrients for Plug Seedling Growth
}

\author{
Jin-Sheng Huang ${ }^{1}$, Paul V. Nelson ${ }^{2}$ Douglas A. Bailey ${ }^{3}$, \\ William C. Fonteno ${ }^{2}$, and Nancy C. Mingis ${ }^{4}$ \\ Department of Horticultural Science, North Carolina State University, Raleigh, \\ NC 27695-7609
}

\begin{abstract}
Additional index words. bedding plants, Impatiens wallerana 'Accent Rose', Gomphrena globosa 'Buddy', root substrate, root media, flowering
\end{abstract}

Abstract. Salinity guidelines for seed germination substrates call for low, difficult to attain levels. This study was conducted to determine the value of $N, P, K$, and $S$ as preplant nutrients, with the anticipation that some could be eliminated to alleviate the high salinity problem in many substrates. Impatiens wallerana L. 'Accent Rose' and Gomphrena globosa L. 'Buddy' were tested in 288-cell plug trays containing a substrate of 3 sphagnum peat moss : 1 perlite $(\mathrm{v} / \mathrm{v})$ in two experiments. Seven preplant $N, P, K$, and $S$ treatments, including none, all (each at $100 \mathrm{mg} \cdot \mathrm{L}^{-1}$ of substrate), all minus one of each of the nutrients, and $\mathrm{N}$ at one additional rate of $50 \mathrm{mg} \cdot \mathrm{L}^{-1}$, were tested. Postplant fertilization was applied to all treatments as $13 \mathrm{~N}-0.9 \mathrm{P}-10.8 \mathrm{~K}$ at $50 \mathrm{mg} \cdot \mathrm{L}^{-1} \mathrm{~N}$ beginning 1 week after sowing and was increased to $100 \mathrm{mg} \cdot \mathrm{L}^{-1} \mathrm{~N}$ when the fourth true leaf appeared. The resultant seedlings were transplanted into 48-cell flats and grown into marketable stage for further evaluation. For maximum potential growth, $\mathbf{N}, \mathbf{P}, \mathrm{K}$, and $\mathrm{S}$ were needed as preplant fertilizer. However, compact shoots, not maximum growth, are generally desired in commercial production. Thus, $K$ and $S$ can be omitted since their contribution to growth was only occasional and small. To further ensure a consistently desirable level of compactness, it was necessary to omit $\mathrm{N}$ or $\mathrm{P}$ or both in addition to $\mathrm{K}$ and $\mathrm{S}$. Omission of $\mathrm{N}$ alone yielded the most desirable compact plant qualities, including suitable reduction in final seedling size. Omission of $P$ alone yielded larger reductions in height and shoot dry weight of seedlings compared to $N$ omission, and a delay of $\mathbf{2}$ to $\mathbf{4}$ days in flowering of bedding plants. Omission of the four nutrients, compared to $-\mathbf{P}$, resulted in similar seedling growth reduction and bedding plant flower delay. Since $\mathbf{N}$ omission lowered the salt (electrical conductivity) level of substrate more than $\mathbf{P}$ omission and had no negative impact on subsequent bedding plant flowering compared to the other two treatments, $\mathrm{N}$ omission would be the more desirable of the three. However, $\mathbf{N}$ omission resulted in chlorotic seedlings, but these quickly turned green upon restoration of $\mathrm{N}$. Omission of $\mathrm{P}$ or all four nutrients resulted in desirably deep green seedlings. Growth of gomphrena seedlings, a high-fertilizer requirement category of taxa, was suppressed when the preplant rate of $\mathrm{N}$ was $50 \mathrm{mg} \cdot \mathrm{L}^{-1}$ compared to $100 \mathrm{mg} \cdot \mathrm{L}^{-1}$, while growth of impatiens, a low-fertilizer requirement category of taxa, was essentially equivalent at these rates. Preplant additions of nutrients applied at $100 \mathrm{mg}$ of nutrient element per liter of substrate lasted for the following numbers of days; $\mathrm{NO}_{3}-\mathrm{N}, 18$ 25 days; $\mathrm{NH}_{4}-\mathrm{N}, 12-20$ days; $\mathrm{K}_{2} \mathrm{O}, 27$ days; $\mathrm{PO}_{4}-\mathrm{P},>35$ days; and $\mathrm{SO}_{4}-\mathrm{S},>35$ days.

Preplant nutrients are those nutrients that are incorporated into the root substrate at the time that it is being formulated. Current recommendations for preplant nutrients include

Received for publication 11 Sept. 2000. Accepted for publication 8 Oct. 2001. This research was funded in part by a grant from Bedding Plants Foundation,Lansing, Mich., and by the North Carolina Agricultural Research Service (NCARS), Raleigh. Use of trade names does not imply endorsement by the NCARS of products named nor criticism of similar ones not mentioned. Appreciation is expressed to Goldsmith Seeds and Park Seed Co. for seeds. From a dissertation submitted by J.S. Huang in partial fulfillment of the requirements for the $\mathrm{PhD}$ degree. ${ }^{1}$ Graduate Assistant.

${ }^{2}$ Professor

${ }^{3}$ Present address: Dept. of Horticulture, Univ. of Georgia, Athens, GA 30602.

${ }^{4}$ Analyst. sources of $\mathrm{NH}_{4}-\mathrm{N}$ and/or $\mathrm{NO}_{3}-\mathrm{N}, \mathrm{PO}_{4}-\mathrm{P}, \mathrm{K}$, $\mathrm{Ca}, \mathrm{Mg}, \mathrm{SO}_{4}-\mathrm{S}$, and micronutrients. These guidelines come from the early soilless container media recommendations for crops, including the Cornell Peat-lite media (Boodley and Sheldrake, 1972), Greenhouse Crops Research Institute media (Bunt, 1988), and textbooks (Nelson, 1998). Common amendment materials include dolomitic limestone, triple superphosphate, gypsum, potassium nitrate, and calcium nitrate (Bunt, 1988; Nelson, 1998; Warncke and Krauskopf, 1983).

Dight (1977) recommended the use of preplant $\mathrm{N}, \mathrm{P}, \mathrm{K}, \mathrm{Ca}$, and $\mathrm{Mg}$ for substrates to be used in finish flat production of bedding plants. $\mathrm{He}$ indicated that $\mathrm{N}$ primarily accounts for the rate of growth of crops. Adams (1996) reported the use of preplant nutrients to be optional for plug seedling substrate. Not every- one agrees that preplant nutrients are optional for seedling substrates. In general, when a preplant charge is used in a plug substrate, it needs to be lower than in general crop substrates. Koranski and Kessler (1996) recommended that $\mathrm{N}, \mathrm{P}, \mathrm{Ca}$, and $\mathrm{Mg}$ should be in the range of $40,5,25$, and $50 \mathrm{mg} \cdot \mathrm{L}^{-1}$ of substrate, respectively. Adams (1996) suggested a preplant fertilizer ratio of major elements for a plug substrate is: $1 \mathrm{~N}-0.25 \mathrm{P}-1 \mathrm{~K}-1 \mathrm{Ca}-0.5 \mathrm{Mg}$.

The amount of preplant nutrient charge to use should be determined based on the substrate salt concentration that seedlings can tolerate. Substrates for plug production should have an electrical conductivity (EC) of 0.75 $\mathrm{dS} \cdot \mathrm{m}^{-1}$ or less as measured in a 1:2 volume substrate : water extract (Styer and Koranski, 1997; Warncke and Krauskopf, 1983). This salinity guideline for seed germination and plug seedling growth is low and difficult to attain given the salinity contributions of components such as peat moss, vermiculite, limestone, wetting agents, and nutrients (Huang and Nelson, 2001). Substrate salinity level could be easily reduced if some preplant macronutrients were deemed superfluous. Calcium and $\mathrm{Mg}$ can not be eliminated, since dolomitic limestone is usually needed in the substrate for $\mathrm{pH}$ adjustment.

The objectives of this study were to: 1) reassess the need for the macronutrients $\mathrm{N}, \mathrm{P}$, $\mathrm{K}$, and $\mathrm{S}$ as preplant nutrients for plug seedling production; 2) determine the impact of omission of these preplant nutrients on bedding plant production subsequent to plug production; and 3) determine the appropriate preplant nitrogen rate if preplant charge is required.

\section{Materials and Methods}

Two experiments were conducted in glass greenhouses in Raleigh, N.C., at lat. $35^{\circ} \mathrm{N}$. Test plants included Impatiens wallerana $\mathrm{L}$. 'Accent Rose'(impatiens) (Goldsmith Seeds, Lot G10185B) and Gomphrena globosa L. 'Buddy' (gomphrena) (Park Seed Co., lot AM08). Impatiens was selected from a list of taxa requiring low fertilizer, and gomphrena from a list requiring high fertilizer (Nelson, 1999). Substrates were formulated with $3 \mathrm{sph}-$ agnum peat moss : 1 perlite $(\mathrm{v} / \mathrm{v})$ amended with $6 \mathrm{~g}$ dolomitic limestone and $1.5 \mathrm{~g}$ Esmigran micronutrient mix (The Scotts Co., Marysville, Ohio) per liter. Mass wetness of substrates was brought up to 2.0 ( $67 \%$ water by weight) prior to filling trays and seeding.

Seven treatments were used in the two experiments (Table 1). Treatments 1-6 were used to address the impact of preplant N, P, K,

Table 1. Treatment combinations in Expts. 1 and 2.

\begin{tabular}{lrrrr}
\hline & \multicolumn{4}{c}{$\begin{array}{c}\text { Preplant nutrients } \\
\text { (mg.L substrate) }\end{array}$} \\
\cline { 2 - 5 } Treatments & $\mathrm{N}$ & \multicolumn{1}{c}{$\mathrm{P}$} & $\mathrm{K}$ & $\mathrm{S}$ \\
\hline 1 & 0 & 0 & 0 & 0 \\
2 & 100 & 100 & 100 & 100 \\
3 & 0 & 100 & 100 & 100 \\
4 & 100 & 0 & 100 & 100 \\
5 & 100 & 100 & 0 & 100 \\
6 & 100 & 100 & 100 & 0 \\
7 & 50 & 100 & 100 & 100 \\
\hline
\end{tabular}


and $\mathrm{S}$ on plug seedling growth and subsequent bedding plant growth and flowering while treatments 2 and 7 addressed the effects of preplant $\mathrm{N}$ quantity. Chemical composition of treatments are shown in Table 2.

Seeds were sown into 288-cell plug trays on 23 Mar. and 6 June 1995 for Expts. 1 and 2, respectively. After sowing, trays were placed in a dark germination chamber at constant 24 ${ }^{\circ} \mathrm{C}$. When radicles emerged and hooked downward (end of stage I), plug trays were moved bench in a randomized complete-block design of three blocks with one tray per experimental unit. Postplant fertilization with $13 \mathrm{~N}-0.9 \mathrm{P}-$ $10.8 \mathrm{~K}$ at $50 \mathrm{mg} \cdot \mathrm{L}^{-1} \mathrm{~N}$ began when all plants reached stage III (first true leaf just appeared). This began 1 week after removal from the germination chamber for impatiens in both experiments and gomphrena in Expt. 1, and 5 $\mathrm{d}$ after removal for gomphrena in Expt. 2. Fertilizer rate was increased to $\mathrm{N}$ at 100 $\mathrm{mg} \cdot \mathrm{L}^{-1}$ when the fourth true leaf appeared. In Expt. 1, fertilizer was applied every second irrigation. Both water and fertilizer were applied with $0 \%$ leaching by sub-irrigation. In Expt. 2 fertilizer was applied at $20 \%$ leaching during each irrigation by first sub-irrigating trays and then applying water or fertilizer overhead to achieve the $20 \%$ leaching rate.

At the start of postplant fertilization (day 0 ), and weekly thereafter, substrates were sampled $1 \mathrm{~h}$ after watering (day 0 ) or $1 \mathrm{~h}$ after fertilization. Substrate samples were squeezed

Table 2. Chemical composition of treatments in both experiments.

\begin{tabular}{lrrlrrrr}
\hline \hline & \multicolumn{7}{c}{ Trmt } \\
\cline { 2 - 7 } Preplant sources & 1 & 2 & 3 & \multicolumn{1}{c}{4} & 5 & 6 & 7 \\
\hline & 0 & 0 & 0 & 0 & 240 & 0 & 0 \\
$\mathrm{Ca}\left(\mathrm{NO}_{3}\right)_{2} \cdot 4 \mathrm{H}_{2} \mathrm{O}$ & 0 & 274 & 0 & 274 & 0 & 274 & 262 \\
$\mathrm{KNO}_{3}$ & 0 & 194 & 0 & 194 & 194 & 194 & 0 \\
$\mathrm{NH}_{4} \mathrm{NO}_{3}$ & 0 & 0 & 0 & 0 & 0 & 0 & 76 \\
$\left(\mathrm{NH}_{4}\right)_{2} \mathrm{SO}_{4}$ & 0 & 0 & 348 & 0 & 0 & 0 & 14 \\
$\mathrm{KH}_{2} \mathrm{PO}_{4}$ & 0 & 500 & 110 & 0 & 500 & 500 & 485 \\
$45 \%$ superphosphate $_{\mathrm{CaSO}} \cdot 2 \mathrm{H}_{2} \mathrm{O}$ & 0 & 538 & 538 & 538 & 538 & 0 & 441 \\
\hline
\end{tabular}
by hand through one layer of cheesecloth Extracted substrate solutions were analyzed for $\mathrm{pH}, \mathrm{EC}, \mathrm{NO}_{3}-\mathrm{N}, \mathrm{NH}_{4}-\mathrm{N}, \mathrm{PO}_{4}-\mathrm{P}, \mathrm{Ca}, \mathrm{Mg}, \mathrm{K}$ and $\mathrm{SO}_{4}-\mathrm{S}$. EC and $\mathrm{pH}$ were measured using a Model $695 \mathrm{pH} /$ conductivity/TDS/temperature meter (Extech Instruments, Waltham, Mass). Colorimetric analysis was performed for $\mathrm{NO}_{3}-$ $\mathrm{N}$ (Caltaldo et al., 1975), $\mathrm{NH}_{4}-\mathrm{N}$ (Chaney and Marbach, 1962), $\mathrm{PO}_{4}-\mathrm{P}$ (concentrations $<10$ $\mu \mathrm{g} \cdot \mathrm{mL}^{-1}$, Murphy and Riley, 1962; and concentrations $>10 \mu \mathrm{g} \cdot \mathrm{mL}^{-1}$, Chapman and Pratt, 1961) and sulfur (Hunter, 1979) on a Model Lambda 3 UV/VIS spetrophotometer (PerkinElmer, Norwalk, Conn.). Atomic absorption spectroscopy was used for $\mathrm{Ca}, \mathrm{Mg}$, and $\mathrm{K}$ analysis.

At the last date of sampling, 36 plants were harvested for shoot height measurement, leaf count, and shoot dry mass. Roots also were washed for dry-mass measurement. Root to shoot dry-mass ratio (R:S) was computed. Stockiness was calculated by dividing shoot dry mass by height. The 36 shoots from each plot were washed in $0.2 \mathrm{~N} \mathrm{HCl}$, rinsed in deionized water, dried at $70{ }^{\circ} \mathrm{C}$, weighed, and ground to $1-\mathrm{mm}$ particle size in a stainless steel Wiley mill. Tissue total $\mathrm{N}$ was analyzed using a Kjeldahl procedure (Fleck, 1974). Ground tissue was dry-ashed at $500{ }^{\circ} \mathrm{C}$, dehydrated in $\mathrm{HCl}$, and dissolved in $0.5 \mathrm{~N} \mathrm{HCl}$. Tissue $\mathrm{P}$ and $\mathrm{S}$ were measured with the same procedure as used for substrate $\mathrm{P}$ and $\mathrm{S}$ analysis. Tissue $\mathrm{K}, \mathrm{Ca}$, and $\mathrm{Mg}$ were measured using atomic absorption spectroscopy. out of the chamber and placed on a greenhouse

Remaining plugs from all treatments were

Table 3. Effects of preplant nutrients on height, shoot dry mass, stockiness, root dry mass, root : shoot ratio (R:S), and number of leaves of plug seedlings in both experiments. Measurements were taken at the end of plug stage.

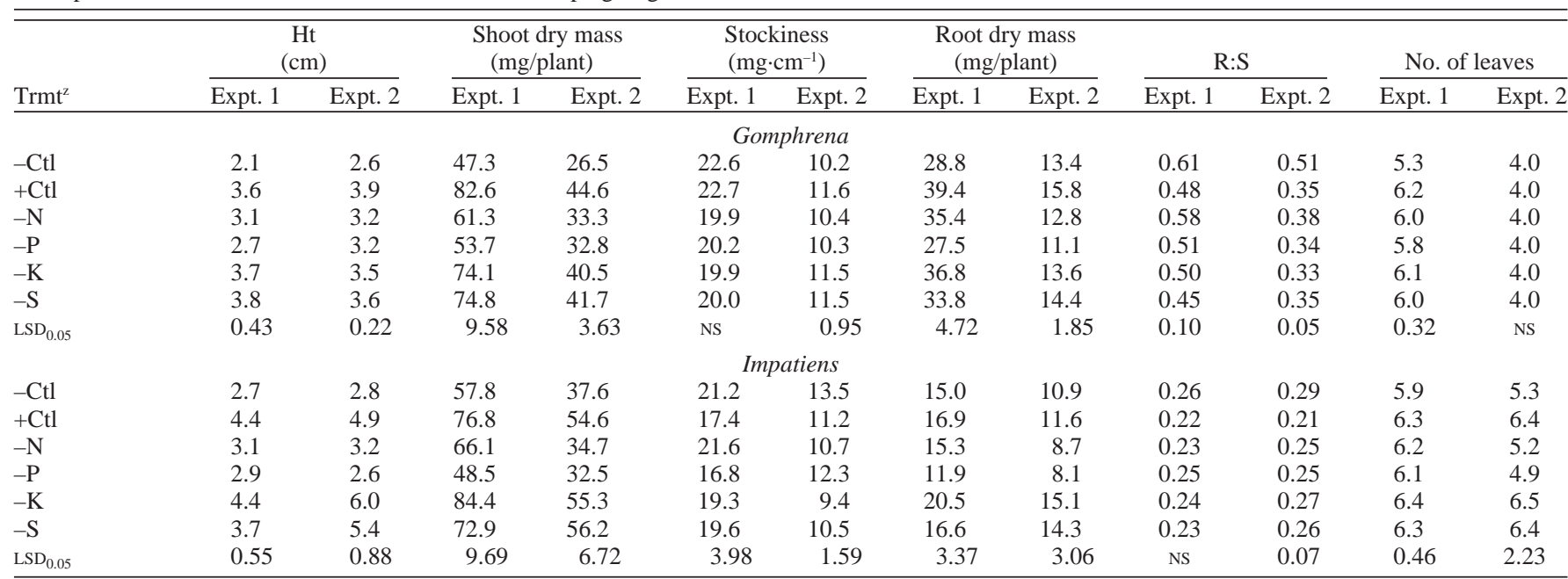

${ }^{2}$ Preplant treatment nutrients included $\mathrm{N}, \mathrm{P}, \mathrm{K}$, and $\mathrm{S}$, with each element at $100 \mathrm{mg} \cdot \mathrm{L}^{-1}$ substrate. None was applied in the $-\mathrm{Ctl}$, all in the $+\mathrm{Ctl}$, and all but the specified nutrient in the remaining treatments.

ss Nonsignificant. transplanted into 48-cell finish flats filled with Bellevue, Wash.) to evaluate the carry-over effect of omission of preplant nutrients on growth and flowering of subsequent bedding plants. The transplant dates for both species in Expts. 1 and 2 were 4 May 1995 and 10 July 1995 , respectively. One flat was planted from each plug tray for a total of three replications. Plants were fertilized weekly after transplanting with $\mathrm{N}$ at $240 \mathrm{mg} \cdot \mathrm{L}^{-1}$ from $20 \mathrm{~N}-4.4 \mathrm{P}$ 16.6K Peters fertilizer (The Scotts Co.). The counted daily. When $60 \%$ of plants bloomed plants was measured and shoots were harvested, washed, dried, weighed, and analyzed for $\mathrm{N}, \mathrm{P}, \mathrm{K}, \mathrm{Ca}, \mathrm{Mg}$, and $\mathrm{S}$ as described above.

All data were subjected to analysis of variance by crop, experiment, and date. Means were separated by least significant differences using SAS (SAS Institute, Cary, N.C.).

\section{Results and Discussion}

\section{combination preplant nutrients on plug seedlings and subsequent bedding plants}

Plug seedlings. Seedlings produced without preplant $\mathrm{N}(-\mathrm{N})$ were light green compared to the plus control-treated plants (treatment 2), particularly during the first half of production. Seedlings produced without preplant $\mathrm{P}(-\mathrm{P})$ or all four nutrients were deeper green throughout production. Seedlings produced without $\mathrm{K}(-\mathrm{K})$ or $\mathrm{S}(-\mathrm{S})$ did not differ in color from the plus control seedlings.

Omission of preplant $\mathrm{N}$ or $\mathrm{P}$ in plug substrate resulted in reduced height and shoot dry mass compared to the + control treatment in gomphrena and impatiens in both experiments (Table 3). $\mathrm{P}$ omission resulted in greater reductions than $-\mathrm{N}$. K omission did not affect number of flowers reaching anthesis was lected from 
final height or shoot dry mass of either crop in Expt. 1 but did reduce height and shoot dry mass of gomphrena in Expt. 2. S omission resulted in reductions in final height of impatiens in Expt. 1 and gomphrena in Expt. 2. Growth reductions caused by $-\mathrm{K}$ and $-\mathrm{S}$ were small compared to those caused by $-\mathrm{N}$ and $-\mathrm{P}$. Omissions of the four preplant nutrients simultaneously resulted in greater height and shoot dry-mass reductions in gomphrena and equal reductions in impatiens in both experiments than did $-\mathrm{N}$ or $-\mathrm{P}$ singly.

Omission of any of the four nutrients individually did not result in changes in final stockiness of impatiens plants in either experiment or gomphrena in the first experiment (Table 3). This indicates that shoot mass and height diminished proportionately whenever reductions occurred. In the second experiment final stockiness of gomphrena was reduced by both $-\mathrm{N}$ or $-\mathrm{P}$, indicating a disproportionately greater reduction in shoot mass than height. Omission of the four nutrients simultaneously, led to similar reductions in stockiness in gomphrena and similar or less reduction in impatiens compared to $-\mathrm{N}$ or $-\mathrm{P}$ individually.

$\mathrm{P}$ omission had the greatest impact of any individual nutrient on root dry mass (Table 3 ). Mass was reduced in both crops in both experiments. Omission of $\mathrm{N}$ or $\mathrm{K}$ resulted in reduction of root mass in gomphrena in Expt. 2 and -S resulted in root mass reduction in gomphrena in Expt. 1. When four nutrients were omitted simultaneously in Expt. 1, root mass reduction was the maximum recorded in the experiment and equal to that from -P. In Expt. 2, root reductions caused by simultaneous omission of the four nutrients caused reductions in root dry mass equal to those caused by $-\mathrm{N}$ alone but not as severe as those caused by $-\mathrm{P}$ alone. The root to shoot dry-mass ratio (R:S) (Table 3) was unaffected in most treatments, indicating that reductions in shoot mass were accompanied by a proportionate reduction in root mass. However, R:S was increased in gomphrena when $\mathrm{N}$ was omitted in Expt. 1 and when all four nutrients were omitted in both experiments. In impatiens, R:S was increased when all four nutrients were omitted in Expt. 2. This is in agreement with reports that low $\mathrm{N}$ stress causes an increase in R:S (Andserson, 1988; Mengel and Kirkby, 1987). Leaf number(Table 3 ) was mostly unaffected. Leaf number was reduced only by omission of $\mathrm{P}$ or all four nutrients simultaneously in gomphrena in Expt. 1.
Bedding plants. Omission of preplant $\mathrm{N}$ in plug seedling root substrate resulted in reduced height in gomphrena and impatiens at the end of bedding plant production in Expt. 1 and reduced gomphrena shoot dry mass in both experiments (Table 4). Omission of $\mathrm{N}$ had no effect on flowering of gomphrena plants in either experiment or on impatiens in Expt. 1 (Table 4). The only exception was in Expt. 2 for impatiens, where there was a delay of $4 \mathrm{~d}$ to reach $60 \%$ of plants in flower.

When preplant $\mathrm{P}$ was omitted, gomphrena dry mass was reduced in both experiments, while height was only reduced in Expt. 1. Growth of impatiens was less affected, with only a reduction in shoot dry mass in Expt. 1. However, -P consistently delayed flowering in the two experiments for both crops. The time required to reach $60 \%$ of plants in bloom was delayed by $2-4 \mathrm{~d}$.

Omission of four nutrients simultaneously compared to omission of $\mathrm{N}$ or $\mathrm{P}$ alone caused less reduction in height and shoot dry mass in Expt. 1 and an equal reduction in Expt. 2. Omission of the four nutrients together extended the time to flowering 4 to $6 \mathrm{~d}$ in gomphrena and 2 to $3 \mathrm{~d}$ in impatiens. Omission of $\mathrm{K}$ had no effect on bedding plant growth in any experiment or crop. Time to flowering was delayed $2 \mathrm{~d}$ in gomphrena in the second experiment. Omission of $\mathrm{S}$ had no effect on flowering, and shoot dry mass was only reduced in Expt. 2 for gomphrena.

Overall, the main impact of preplant nutrient omissions in plug substrate on bedding plant growth was caused by omissions of $\mathrm{N}$ or $\mathrm{P}$ or all four nutrients. S omission effects were relatively small and -K had no effect. Carryover of growth suppression from plug seedlings to bedding plants would generally be considered commercially desirable. Since omission of $\mathrm{N}$ or $\mathrm{P}$ or all four nutrients during plug seedling production had the greatest carryover effects on growth suppression during bedding plant production, these would be the three most desirable strategies. There were undesirable delays in flowering that accompanied these growth suppressions, but chemical plant growth regulators also have similar problems delaying flowering.

Effects of preplant $N$ rates on growth of plug seedlings and subsequent bedding plants. When preplant application of $\mathrm{N}$ was reduced from 100 to $50 \mathrm{mg} \cdot \mathrm{L}^{-1}$, there were no effects on final seedling height, root dry mass, stockiness, root : shoot ratio, or number of leaves in gomphrena or impatiens seedlings in either experiment (data not shown). Shoot dry mass did not differ in impatiens in either experiment nor in gomphrena in Expt. 2. But, shoot dry mass was lower in gomphrena seedlings in the second experiment when they were grown in substrate with $50 \mathrm{mg} \mathrm{N}$ compared to $100 \mathrm{mg} \mathrm{N}$ (38.8 vs. $44.6 \mathrm{mg}$ shoot mass per plant). The preplant $\mathrm{N}$ rate in seedling substrate had no carry-over effects on height, shoot dry mass, or days to $60 \%$ flower in the subsequent bedding plant crop (data not shown). It is not surprising that the shoot dry mass difference occurred in gomphrena, since the nutrient requirement of gomphrena is high compared to impatiens (Nelson, 1999). Results suggest that a preplant rate of $\mathrm{N}$ at $50 \mathrm{mg} \cdot \mathrm{L}^{-1}$ substrate is sufficient for taxa in the light-fertilizer requirement category to achieve the same high rate of growth stimulated by $\mathrm{N}$ at $100 \mathrm{mg} \cdot \mathrm{L}^{-1}$ substrate in the group of taxa requiring heavy fertilizer.

Preplant nutrient longevity. Longevity of preplant nutrients was determined by noting the dates when root substrate concentrations remained significantly higher in the control treatment than in the corresponding minus preplant nutrient treatment. $\mathrm{NO}_{3}-\mathrm{N}$ was significantly higher in gomphrena substrate in Expt. 1 at $18 \mathrm{~d}$ but not $25 \mathrm{~d}$ after sowing (Table 5). Thus, preplant $\mathrm{NO}_{3}-\mathrm{N}$ ran out after $18 \mathrm{~d}$ but before $25 \mathrm{~d}$. When this pair of dates was averaged for the two experiments, preplant $\mathrm{NO}_{3}-\mathrm{N}$ was again found to run out between 18 and $25 \mathrm{~d}$ after sowing. The average duration of preplant $\mathrm{NH}_{4}-\mathrm{N}$ was 12 to $20 \mathrm{~d}$ and for $\mathrm{K}$ it was 20 to $27 \mathrm{~d}$ after sowing. Preplant $\mathrm{PO}_{4}-\mathrm{P}$ and $\mathrm{SO}_{4}-\mathrm{S}$ persisted for the entire duration of each experiment, which averaged $35 \mathrm{~d}$. Sub-irrigated treatments (Expt.1) tended to last longer for most preplant nutrients than $20 \%$ leaching (Expt. 2). The longevity of preplant $\mathrm{NO}_{3}-\mathrm{N}$ and $\mathrm{K}$ was $\approx 5 \mathrm{~d}$ longer in Expt. 1 with no leaching, than in Expt. 2 with $20 \%$ leaching.

Effects of omission of preplant nutrients on plug and bedding plant tissue nutrient content. Omission of preplant $\mathrm{P}, \mathrm{K}$, and $\mathrm{S}$ resulted in reduced concentrations of these nutrients in seedling tissue at the end of production, except for impatiens in Expt. 2, where the tissue concentration was not lower (Table 6). Unlike the other treatment nutrients, tissue $\mathrm{N}$ was not lower when preplant $\mathrm{N}$ was omitted. This indicates that plant biomass accumulation proceeded in proportion to $\mathrm{N}$ supply but not the supply of the other three nutrients.

Table 4. Effects of preplant nutrients in the plug seedling substrate on final height, final shoot dry mass, and flowering of a subsequent bedding plant crop.

\begin{tabular}{|c|c|c|c|c|c|c|c|c|c|c|c|c|}
\hline \multirow[b]{3}{*}{$\operatorname{Trmt}^{2}$} & \multicolumn{4}{|c|}{$\mathrm{Ht}(\mathrm{cm})$} & \multicolumn{4}{|c|}{ Shoot dry mass (g/plant) } & \multicolumn{4}{|c|}{ Days of $60 \%$ plants in flowering } \\
\hline & \multicolumn{2}{|c|}{ Gomphrena } & \multicolumn{2}{|c|}{ Impatiens } & \multicolumn{2}{|c|}{ Gomphrena } & \multicolumn{2}{|c|}{ Impatiens } & \multicolumn{2}{|c|}{ Gomphrena } & \multicolumn{2}{|c|}{ Impatiens } \\
\hline & Expt. 1 & Expt. 2 & Expt. 1 & Expt. 2 & Expt. 1 & Expt. 2 & Expt. 1 & $\overline{\text { Expt. } 2}$ & Expt. 1 & $\overline{\text { Expt. } 2}$ & Expt. 1 & Expt. 2 \\
\hline$-\mathrm{Ctl}$ & 11.4 & 20.8 & 8.3 & 17.5 & 0.3 & 0.8 & 0.2 & 0.5 & 18.1 & 30.0 & 10.2 & 18.4 \\
\hline$-\mathrm{N}$ & 12.2 & 21.0 & 9.4 & 18.8 & 0.4 & 0.8 & 0.3 & 0.5 & 12.0 & 26.0 & 8.0 & 18.6 \\
\hline$-\mathrm{P}$ & 12.1 & 22.1 & 10.1 & 17.6 & 0.4 & 0.8 & 0.2 & 0.4 & 16.2 & 28.0 & 12.0 & 19.3 \\
\hline$-\mathrm{K}$ & 13.8 & 20.6 & 10.5 & 18.4 & 0.4 & 0.8 & 0.3 & 0.5 & 12.8 & 28.0 & 7.4 & 15.0 \\
\hline$-\mathrm{S}$ & 12.7 & 19.3 & 10.1 & 18.9 & 0.4 & 0.7 & 0.3 & 0.5 & 13.7 & 27.0 & 7.3 & 15.0 \\
\hline
\end{tabular}

${ }^{2}$ Preplant treatment nutrients included $\mathrm{N}, \mathrm{P}, \mathrm{K}$, and $\mathrm{S}$, with each element at $100 \mathrm{mg} \cdot \mathrm{L}^{-1}$ substrate. None was applied in the $-\mathrm{Ctl}$, all in the $+\mathrm{Ctl}$, and all but the specified nutrient in the remaining treatments.

${ }^{n s}$ Nonsignificant. 
Table 5. Weekly plug seedling substrate analyses for both experiments. Substrate solutions were extracted by squeezing from substrate.

\begin{tabular}{|c|c|c|c|c|c|c|c|c|c|c|c|}
\hline \multirow[b]{3}{*}{ Trmt } & \multicolumn{11}{|c|}{ Gomphrena } \\
\hline & \multicolumn{6}{|c|}{ Expt. 1} & \multicolumn{5}{|c|}{ Expt. 2} \\
\hline & $0^{\mathrm{z}}$ & 11 & 18 & 25 & 32 & 39 & $0^{2}$ & 6 & 13 & 20 & 27 \\
\hline & & \multicolumn{10}{|c|}{$\mathrm{NO}_{3}-N\left(m g \cdot L^{-1}\right)$} \\
\hline$-\mathrm{N}$ & 70.3 & 65.2 & 60.8 & 20.4 & 40.6 & 48.7 & 30.3 & 46.7 & 24.8 & 21.0 & 28.5 \\
\hline \multirow[t]{2}{*}{$\operatorname{LSD}_{0.05}$} & 17.14 & 36.60 & 35.27 & NS & NS & NS & 7.00 & 20.42 & 12.45 & NS & 7.65 \\
\hline & & \multicolumn{10}{|c|}{$\mathrm{NH}_{4}-\mathrm{N}\left(m g \cdot L^{-1}\right)$} \\
\hline \multirow[t]{2}{*}{$\mathrm{LSD}_{0.05}$} & 4.13 & 8.49 & NS & 0.91 & NS & NS & 3.75 & 7.52 & 2.90 & 0.45 & 0.20 \\
\hline & & \multicolumn{10}{|c|}{$P\left(m g \cdot L^{-1}\right)$} \\
\hline$+\mathrm{Ctl}$ & 79.9 & 37.6 & 15.4 & 4.0 & 2.5 & 1.9 & 91.4 & 92.1 & 59.6 & 18.8 & 8.2 \\
\hline$-\mathrm{P}$ & 1.9 & 2.0 & 1.6 & 0.7 & 0.5 & 0.5 & 0.5 & 1.5 & 5.2 & 4.4 & 4.4 \\
\hline \multirow[t]{2}{*}{$\mathrm{LSD}_{0.05}$} & 11.03 & 8.17 & 12.64 & 2.51 & 0.47 & 1.13 & 5.83 & 8.42 & 13.17 & NS & 2.14 \\
\hline & & \multicolumn{10}{|c|}{$K\left(m g \cdot L^{-1}\right)$} \\
\hline$+\mathrm{Ctl}$ & 236.6 & 156.2 & 99.2 & 130.2 & 131.0 & 150.2 & 176.6 & 183.6 & 158.6 & 131.4 & 82.4 \\
\hline$-S$ & 90.5 & 45.1 & 52.0 & 77.8 & 82.8 & 112.0 & 69.0 & 83.5 & 83.5 & 62.9 & 43.7 \\
\hline \multirow[t]{3}{*}{$\mathrm{LSD}_{0.05}$} & 24.56 & 33.91 & 19.67 & 19.00 & 23.75 & 35.66 & 10.17 & 27.35 & 11.18 & 27.07 & 26.65 \\
\hline & & \multicolumn{10}{|c|}{ Impatiens } \\
\hline & & \multicolumn{10}{|c|}{$\mathrm{NO}_{3}-\mathrm{N}\left(\mathrm{mg} \cdot \mathrm{L}^{-1}\right)$} \\
\hline$+\mathrm{Ctl}$ & 168.3 & 133.7 & 158.0 & 24.5 & 40.5 & 36.3 & 133.3 & 110.7 & 28.4 & 40.2 & 42.2 \\
\hline$-\mathrm{N}$ & 70.3 & 91.6 & 80.3 & 22.1 & 53.9 & 40.7 & 30.3 & 31.8 & 16.7 & 34.3 & 31.8 \\
\hline \multirow{2}{*}{$\mathrm{LSD}_{0.05}$} & 17.14 & NS & 56.32 & NS & NS & NS & 7.00 & 36.24 & 4.76 & NS & NS \\
\hline & & \multicolumn{10}{|c|}{$\mathrm{NH}_{4}-\mathrm{N}\left(\mathrm{mg} \cdot \mathrm{L}^{-1}\right)$} \\
\hline$+\mathrm{Ctl}$ & 40.2 & 16.0 & 2.8 & 1.2 & 0.8 & 1.1 & 52.5 & 41.9 & 1.3 & 0.8 & 0.9 \\
\hline$-\mathrm{N}$ & 10.6 & 7.1 & 2.4 & 0.9 & 2.0 & 0.6 & 24.9 & 9.0 & 1.5 & 1.3 & 0.8 \\
\hline $\mathrm{LSD}_{0.05}$ & 4.13 & 8.78 & NS & NS & NS & NS & 3.75 & 5.74 & NS & NS & NS \\
\hline$+\mathrm{Ctl}$ & 236.6 & 110.2 & 122.5 & 112.5 & 120.8 & 121.2 & 176.6 & 145.8 & 122.9 & 68.8 & 34.9 \\
\hline$-S$ & 90.5 & 54.4 & 62.5 & 69.7 & 78.4 & 83.7 & 69.0 & 60.1 & 72.0 & 29.3 & 16.4 \\
\hline $\mathrm{LSD}_{0.05}$ & 24.56 & 38.25 & 32.08 & 11.15 & 26.99 & 21.42 & 10.17 & 34.98 & 27.16 & 22.85 & 16.49 \\
\hline
\end{tabular}

${ }^{2}$ Days from sowing.

${ }^{\text {Ns Nonsignificant }}$

Tissue analysis of the subsequent bedding plant crops showed that none of the treatment nutrients $\mathrm{N}, \mathrm{P}, \mathrm{K}$, and $\mathrm{S}$ were lower as a consequence of omitting them in the plug seedling substrate (data not shown).

\section{Summary}

It is not necessary in plug seedling substrate to use all of the preplant nutrients that are standard in greenhouse root substrates. Based on the requirements of impatiens and gomphrena, a lightly and a heavily fertilized crop, respectively, this study indicated that $\mathrm{K}$ and $\mathrm{S}$ can be eliminated with little or no consequences when maximum growth of seedlings is desired. Further cuts can be made when nutrition is altered to yield compact seedlings, which is the customary production practice. In this latter situation $\mathrm{N}$ or $\mathrm{P}$ or both can be omitted in addition to $\mathrm{K}$ and S. Omission of $\mathrm{N}$ was shown to be the preferred method of the three since it had the least adverse impact on flowering of subsequent bedding plants. Elimination of preplant N, K, and $S$ will result in a considerable reduction in substrate EC and make it more feasible to follow the substrate EC guidelines for seedlings.

\section{Literature Cited}

Adams, R. 1996. Make your own plug media, p. 64 66. In: D. Hamrick. 2nded. Grower talks on plug II. Ball Publ., Batavia, Ill.

Anderson, E.L. 1988. Tillage and N fertilization effects on maize root growth and root : shoot ratio. Plant Soil 108:245-251.

Mengel, K. and E. A. Kirkby. 1987. Principles of plant nutrition. 4th ed. Intl. Potash Inst., Berne, Switzerland.

Boodley, J.W. and R. Sheldrake, Jr. 1972. Cornell Peat-lite mixes for commercial plant growing. N.Y. Coll. Agr. Info. Bul. 43.

Bunt, A.C. 1988. Media and mixes for container-
Table 6. Concentrations of N, P, K, and $\mathrm{S}$ in seedling shoot at end of Expts. 1 and 2.

\begin{tabular}{|c|c|c|c|c|}
\hline \multirow[b]{2}{*}{ Trmt } & \multicolumn{2}{|c|}{ Gomphrena } & \multicolumn{2}{|c|}{ Impatiens } \\
\hline & Expt. 1 & Expt. 2 & Expt. 1 & Expt. 2 \\
\hline & & ------ & b) - & ------- \\
\hline +Control & 1.68 & 2.58 & 2.35 & 2.29 \\
\hline$-\mathrm{N}$ & 1.54 & 2.60 & 2.17 & 2.53 \\
\hline $\mathrm{LSD}_{0.05}$ & NS & NS & NS & 0.17 \\
\hline +Control & 0.46 & 0.77 & 0.38 & 0.49 \\
\hline$-\mathrm{P}$ & 0.11 & 0.14 & 0.13 & 0.11 \\
\hline $\mathrm{LSD}_{0.05}$ & 0.04 & 0.03 & 0.04 & 0.05 \\
\hline+ Control & 3.06 & 2.48 & 2.64 & 1.59 \\
\hline$-\mathrm{K}$ & 2.43 & 1.73 & 1.88 & 1.20 \\
\hline $\mathrm{LSD}_{0.05}$ & 0.45 & 0.30 & 0.23 & 0.26 \\
\hline +Control & 0.27 & 0.46 & 0.49 & 0.49 \\
\hline$-\mathrm{S}$ & 0.20 & 0.41 & 0.42 & 0.46 \\
\hline $\mathrm{LSD}_{0.05}$ & 0.02 & 0.03 & 0.03 & NS \\
\hline
\end{tabular}

${ }^{\mathrm{N}}$ Nonsignificant. 
grown plants. Unwin Hyman, London.

Cataldo, D.A., M. Haroon, L.E. Schrader, and V.L. Youngs. 1975. Rapid colorimetric determination of nitrate in plant tissue. Commun. Soil Sci. Plant Anal. 6(1):71-80.

Chaney, A.L. and E.P. Marbach. 1962. Modified reagents for determination of urea and ammonium. Clinical Chem. 8(2):130-132.

Chapman, H.D., and P.F. Pratt. 1961. Methods of analysis for soil, plants, and waters. Univ. Calif., Div. Agr. Sci., p.169-170.

Dight, R.J.W. 1977. Nutritional requirements of bedding plants. Expt. Hort. 29:63-71.

Fleck, A. 1974. Micro determination of nitrogen. Crit. Rev. Anal. Chem. 4:141.
Huang, J.S. and P.V. Nelson. 2001. Impact of preplant root substrate amendments on soilless substrate $\mathrm{EC}, \mathrm{pH}$, and nutrient availability. Commun. Soil Sci. Plant Anal. 32(17/18):2863 2875.

Hunter, A.N. 1979. Unpublished procedure of Dr. Arvel N. Hunter. Address (Apr. 1979): Custom Laboratory Equipment, P.O. Box 757, Orange City, FL 32763.

Koranski, D.S. and R. Kessler. 1996. Seed germination, p. 114-116. In: D. Hamrick. 2nd ed. Grower talks on plug II. Ball Publ., Batavia, Ill.

Murphy, J. and J.P. Riley. 1962. A modified single solution for the determination of phosphate in natural waters. Anal. Chem. Acta. 27:331-36.
Nelson, P.V. 1998. Greenhouse operation and management. 5thed. Prentice Hall, Englewood Cliffs, N.J.

Nelson, P.V. 1999. Nutrition. In: C.A. Buck, S.A Carver, M.L. Gaston, P.S. Konjoian, L.A Kunkle, and M.F. Wilt (eds.). Tips on growing bedding plants. 4th ed. Ohio Florists' Assoc. Columbus.

Styer, R.C. and D.S. Koranski. 1997. Plug and transplant production-A grower's guide. Ball Publ., Batavia, Ill.

Warncke, D.D. and D.M. Krauskopf. 1983. Greenhouse growth media: Testing and nutrition guidelines. Mich. State Univ. Coop. Ext. Ser. Bul. E1736. 